\title{
A rare case of massive cutaneous metastases in breast carcinoma
}

\author{
James Holton, ${ }^{1}$ George Chapman ${ }^{2}$
}

${ }^{1}$ Department of Orthopaedics, Oxford University Hospitals,

Oxford, UK

${ }^{2}$ Department of Geriatrics, Oxford University Hospitals, Oxford, UK

\section{Correspondence to}

Dr James Holton, holton1404@gmail.com

\section{(1) CrossMark}

To cite: Holton J, Chapman G. BMJ Case Rep Published online: [please include Day Month Year] doi:10.1136/bcr-2013202839

\section{DESCRIPTION}

An 82-year-old woman with a medical history of breast carcinoma presented with fatigue and failure to cope at home. Widespread malignant disease was found, including multiple cutaneous lesions and pulmonary metastases. Following review from the local oncology unit, the decision was taken to proceed with palliative care and the patient died 1 week later.

This image (figure 1), taken on admission, shows a large nodular cutaneous metastatic carcinoma. The nodular form is the most common manifestation of cutaneous spread from breast carcinoma. ${ }^{1}$ However, deep ulceration is evident, which is a rare feature of nodular cutaneous metastatic carcinoma. Other forms of cutaneous metastases from breast carcinoma include telangiectatic, en cuirasse and inflammatory metastatic carcinoma.

Cutaneous metastases are more commonly found in the context of breast carcinoma than any other malignancy. A large retrospective study showed

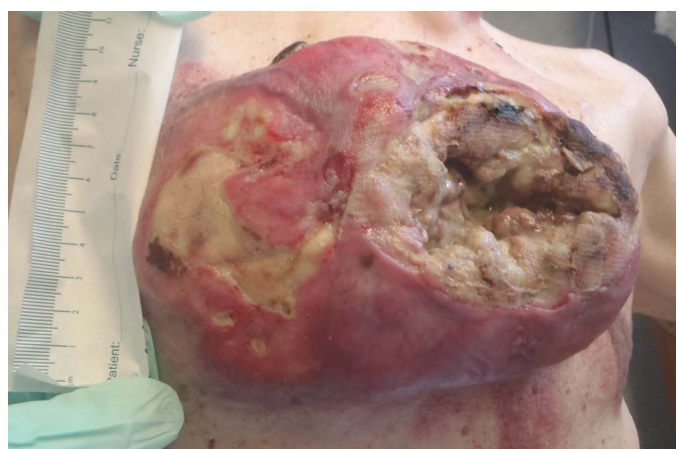

Figure 1 Image showing a massive fungating cutaneous metastasis on the patient's back.
$23.9 \%$ of women with metastatic breast carcinoma had cutaneous metastases. ${ }^{1}$ In addition, the presence of cutaneous metastases from breast carcinoma often indicates widespread dissemination of disease and therefore carries a poor prognosis. ${ }^{2}$ Treatment is often palliative. Recognising cutaneous metastases gives clinicians a better insight into the patient's prognosis, and therefore guidance towards the appropriate investigations and further management for each individual.

\section{Learning points}

- Breast carcinoma is the most common malignancy to give rise to cutaneous metastases.

- The presence of cutaneous metastases in the context of breast carcinoma often signifies widespread metastatic disease and carries a poor prognosis.

Acknowledgements Both authors would like to thank Abingdon Community Hospital for their help and support. They would also like to thank Dr Thompson who as the lead clinician in the department provided the authorisation to submit this work.

\section{Competing interests None.}

Patient consent None.

Provenance and peer review Not commissioned; externally peer reviewed.

\section{REFERENCES}

1 Lookingbill DP, Spangler N, Helm KF. Cutaneous metastases in patients with metastatic carcinoma: a retrospective study of 4020 patients. J Am Acad Dermatol 1993:29(2 Pt 1):228-36.

2 Kalymykow B, Walker $\mathrm{S}$. Cutaneous metastases in breast cancer. Clin J Oncol Nurs 2011:15:99-101.

Copyright 2014 BMJ Publishing Group. All rights reserved. For permission to reuse any of this content visit http://group.bmj.com/group/rights-licensing/permissions.

BMJ Case Report Fellows may re-use this article for personal use and teaching without any further permission.

Become a Fellow of BMJ Case Reports today and you can:

- Submit as many cases as you like

- Enjoy fast sympathetic peer review and rapid publication of accepted articles

- Access all the published articles

- Re-use any of the published material for personal use and teaching without further permission

For information on Institutional Fellowships contact consortiasales@bmjgroup.com

Visit casereports.bmj.com for more articles like this and to become a Fellow 